\title{
Redesign of Leg Prosthetic Clamp Adapter Component Made of Aluminium Mg5085 by using CAD and CAE
}

\author{
F. Y. Prabowo',* and Suyitno ${ }^{2}$ \\ 1Department of Mechanical and Industrial Engineering, Faculty of Engineering, Universitas Gadjah Mada. \\ Jl. Grafika 2, Yogyakarta 55281, Indonesia \\ ${ }^{2}$ Centre for Innovation of Medical Equipment and Devices (CIMEDs), Faculty of Engineering, Universitas Gadjah Mada. \\ Jl. Grafika 2, Yogyakarta 55281, Indonesia \\ *e-mail: fajar.31yuliantop@gmail.com
}

\begin{abstract}
Abstrak
Designing used CAD (Computer Aided Design) to create a design and analyzing the clamp adapter on the leg prosthetic component by using CAE (Computer Aided Engineering) had already been done. This research background is due to a failure on the part of the leg prosthetic component whereas the aim of this research is intended being able to design a leg prosthetic clamp adapter to be able to withstand $300 \mathrm{~kg} l o a d$. Aluminium $\mathrm{Mg}$ 5085 is the material to make this clamp adapter then $300 \mathrm{~kg}$ loading test is conducted. $300 \mathrm{~kg}$ weight is chosen as considered having the average weight of adults who suffer obesity. The result showed that the hugest stress is $25.41 \mathrm{MPa}$, the biggest displacement $6.876 \mathrm{~mm}$, and $0.1345 \mathrm{~mm}$ stress. This analysis result is far lower from yield strength aluminium $\mathrm{Mg}$ which is $140 \mathrm{MPa}$. Hence, this design can be said safe and can be tested further.
\end{abstract}

Keywords: Leg Prosthetic, CAD, Aluminium Mg 5085

\begin{abstract}
Abstrak
Perancangan menggunakan bantuan CAD (Computer Aided Design) untuk membuat desain dan menganalisis clamp adaptor pada komponen kaki palsu telah dilakukan. Penelitian ini bertujuan untuk merancang sebuah klem adaptor pada bagian kaki palsu agar lebih kuat menahan beban $300 \mathrm{Kg}$. Bahan yang digunakan dalam pembuatan klem adaptor adalah Alumunium Mg, dengan dilakukan pembebanan $300 \mathrm{~kg}$ setara dengan berat badan orang dewasa yang mengalami obesitas atau kegemukan. Hasil pengujian menunjukan tegangan terbesar $25.41 \mathrm{Mpa}$, displasment terbesar $6.876 \mathrm{~mm}$, sedangkan untuk regangan sebesar $0.1345 \mathrm{~mm}$, dari hasil analisis ini, jauh lebih rendah dari yield strenght alumunium Mg yaitu sebesar $140 \mathrm{Mpa}$. Sehingga desain tersebut dapat dikatakan aman dan dapat dilakukan pengujian selanjutnya.
\end{abstract}

Kata kunci: Kaki palsu, CAD, Alumunium Mg.

\section{INTRODUCTION}

People disability due to loss their leg functions after getting amputation is a serious problem; therefore a leg prosthetic is used (Bernadheta, 2010). Hopefully this leg prosthetic can replace the sufferer movement problems so that they can live their daily life as others (Toha, 2007).

Leg prosthetic productions in Indonesia itself are mostly imported from abroad. The local products are extremely limited and considered still ancient or traditional in the scope of 
technology. Hence, to produce a better quality, an advanced technology which has higher usability is waited by Indonesian leg prosthetic users (Cristhoper, 2017).

Therefore, a redesign of leg prosthetic which refers to the data of Asians anthropometry is conducted ( $\mathrm{Lin}, 2014)$. Another reason is to fulfill the market needs to replace the existing imported products where further can produce a design that will be able to withstand $300 \mathrm{~kg}$ load or suitable with the weight of adults who suffer obesity. A CAD software is utilized to create a design of leg prosthetic clamp adapter whereas CAE software and then to analyze whether the design of clamp adapter made from Aluminium Mg 5085 is capable to withstand $300 \mathrm{~kg}$ load or not.

\section{METODOLOGY}

Generally, conducting data analysis and load distribution are the methods that mostly researchers used (Fish, 2007). The analysis process of this research needs several steps, those are (1) designing by using CAD software, (2) material determinations which will be used, (3) load determinations $(300 \mathrm{Kg})$, it is considered from the weight of adults who suffer obesity, (4) foothold/constraints determination, (5) meshing process, it is a process dividing the model becoming several elements that are restricted by their boundary condition. A solid mesh type is used to this process.

Figure 1. It shows the free body diagram of the loading that occurs on the leg prosthetic component in the form of a clamp adapter. At the post processor step, the run software is conducted (running the application of calculation or analysis). It is used to obtain the test results in the form of stress, displacement and strain (Steffen, 2016).
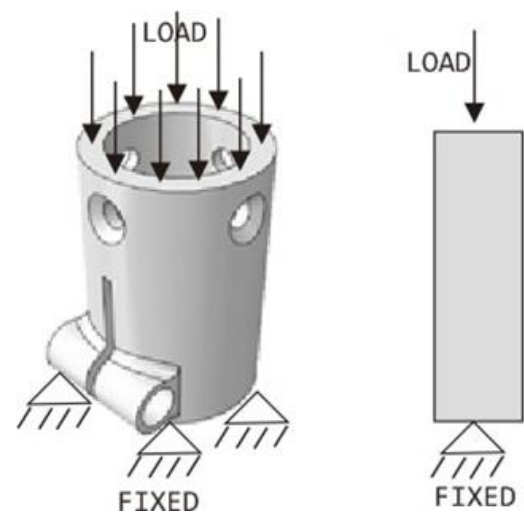

Figure 1. Free body diagram of the clamp adapter the leg prosthetic

\section{RESULTS AND DISCUSSIONS}

CAD software is used in making clamp adapter models because it is capable to compute the strength of leg prosthetic component and design its clamp adapter.

Figure 2. shows the shape of leg prosthetic clamp adapter component made from 5085. The shape looks simple because its produced component is included K2 category which its specification is capable to do the daily activities and lifting load to work. 


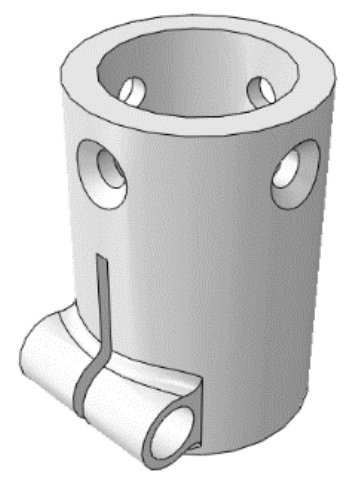

Figure 2. Clamp adapter of the leg prosthetic

Firstly, it is decided which materials that will be used before the calculation simulation of leg prosthetic clamp adapter component by using CAD software. The material that will be used is Aluminium Alloy series 5 or Al Mg which its standard name called ANSY/AA 5085, which in previous case it used AL Alloy 4 series and it was failed in designing the clamp adapter on leg prosthetic. Load determination towards its clamp adapter is taken from the weight of adults who suffer obesity that mostly reached on $300 \mathrm{~kg}$ weight.

The determination of foothold (constraint) is where we decide its clamp adapter on leg prosthetic component towards the anvil or foothold. It's same as when we walking on a building floor or other flat walking media, we can slip or damage its foothold. At this step, the foothold of leg prosthetic component that contacts with the floor is considered as fixed foothold.

Meshing is a process by which geometry as a whole divided into small elements. These small elements will later act as volume or surface controls in the calculation process, then each of these elements will be an input to the elements next to them. This will be continuously happening repeatedly until the domain is fulfilled. In meshing step, the elements that will be selected are adjusted to the geometric shape and needs. Using CAE software, it is certainly becoming easier because at this meshing step, automatic or manual meshing is performed. The understanding of automatic meshing is the software itself determines the size of small elements to near tangible results.

Post processor is the next step to see the results of the simulation using CAE software that has been done. In seeing the results of CAE software simulation is quite easy. The difficulty in this step lies in the part of how to read the results of the simulation. The simulation results will get the stress number (von Mises), displacement and stress by the clamp adapter on the leg prosthetic component made from Aluminium $\mathrm{Mg}$.

Figure 3. It shows the results of the stress (von Misies) that occurs in the clamp adapter component of the leg prosthetic with AL 5085 Aluminum Mg material tested. The stress (von Misies) that occurs in the clamp adapter component of the leg prosthetic is quite large and it occurs in the fastening bolt hole. This can be seen by the presence of a green color gradient on the leg prosthetic component. For this component Al5085 is used and the stress received is 25.41 MPa. 


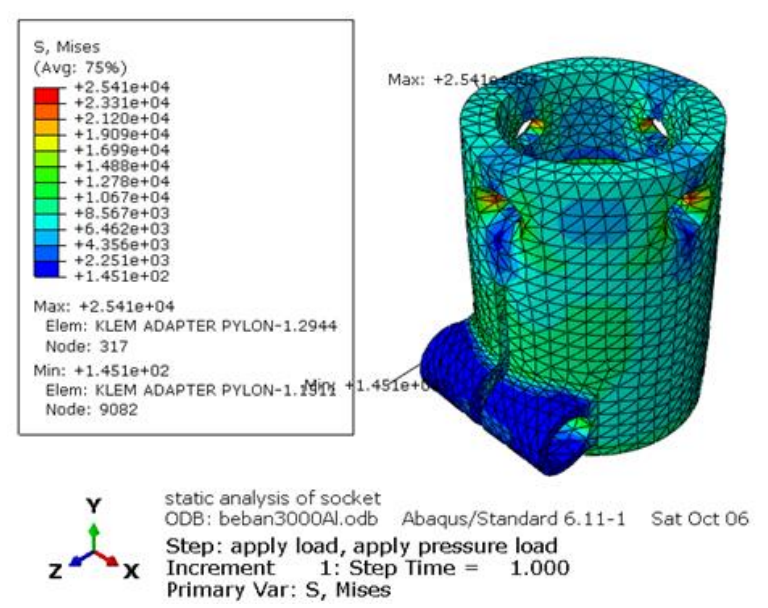

Figure 3. Stress distribution of the component of leg prosthetic

Figure 4. shows the results of the displacement that occurs in the A15085 material being tested. A displacement occurs at the top on the $\mathrm{Y}$ axis. This can be seen in that area from the color gradient that occurs there. There is a displacement that occurred at $6.876 \mathrm{~mm}$ AL 5085 at the $\mathrm{Mg}$ material on the leg prosthetic component.
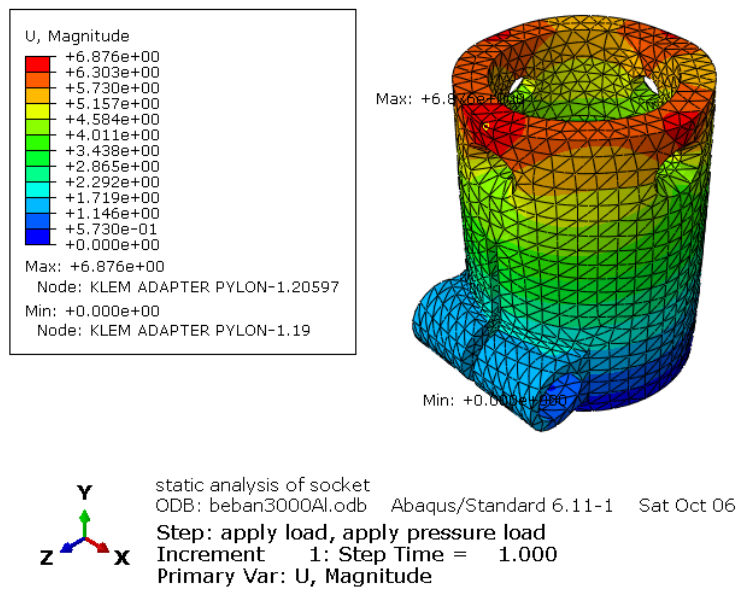

Figure 4. Displacement the component of the leg prosthetic

Figure 5. shows the strain results happening at $\mathrm{Mg}$ that is being tested. Strain that happens at the leg prosthetic component can be seen at the top or on the $\mathrm{Y}$ axis. It is seen from the color gradient that looks light green. A strain that happens in the component of 5083 material is $0.1345 \mathrm{~mm}$. 

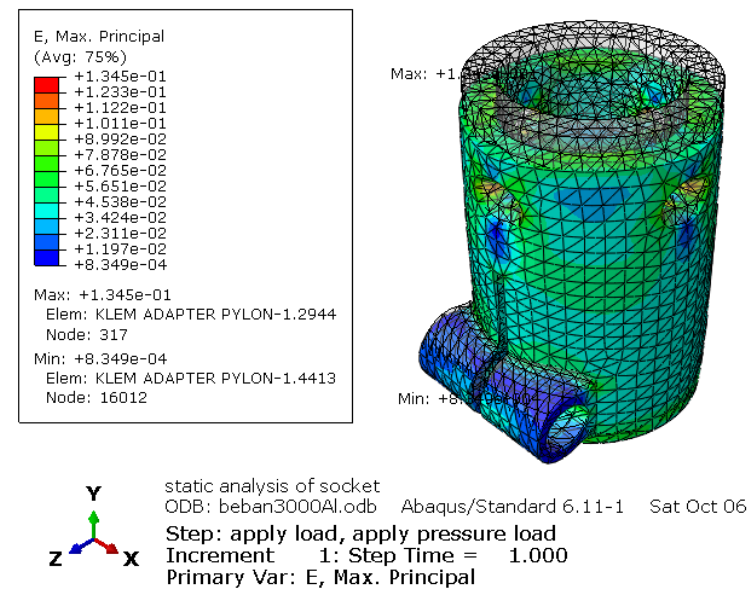

Figure 5. Strain distribution of the component of leg prosthetic

\section{CONCLUSION}

The simulation results of using CAD and CAE software got several data, those are; a maximum stress that is produced from 5083 prosthetic leg component testing is $25.41 \mathrm{MPa}$. If the stress on the component of the prosthetic leg is less than the yield strength of Al5085, the material used for the prosthetic leg component is still safe. The obtained displacement for prosthetic leg made of Al5085 components is $6.876 \mathrm{~mm}$.

\section{REFERENCES}

Bernadheta, F. H., Thesis: Kajian Dynamic Gait Bagi Pengguna Prosthetic Atas Lutut Endoskeletal Sistem Energy Storing dengan Mekanisme 2 Bar, Industrial Engineering Department, Faculty of Engineering, Sebelas Maret University, Surakarta, 2010.

Cristhoper, W.A., Thesis: Evaluasi Lower Limb Prosthetics Produk Pusat Rehabilitasi Yakkum Yogyakarta, Industrial Engineering Department, Faculty of Engineering, Gadjah Mada University, 2017.

Fish, J., dan Belytschko, T., A First Course in the Finite Elements, John Wiley and Sons, Ltd, USA, 2007.

Fisher, F., Modelling and simulation. Steven Institut of Technology, 2011.

Lin, C.Y., The comparisons of Anthropometric Characteristics among Four Peoples in East Asia, http://www.sciencedirect.com, 2004.

Steffen, J., Analysis of Machine Elements Using Solidwork Simulation, 2016.

Toha, Isa Setiasyah. www.rd.lspitb.org, accessed on 2 December 2009 http:/ /www.rd.lspitb.org/ protesa.pdf, 2009. 